\title{
Impact of Covid-19 Outbreak on Teaching and Learning in Public Secondary Schools in South-West Nigeria
}

\author{
Bamire Felicia Bosede* Oparinde Olayiwola Raheef \\ Department of Educational Management, Faculty of Education, Obafemi Awolowo University, Ile-Ife, Osun \\ State, Nigeria \\ *E-mail of the corresponding author: fbamire92@gmail.com
}

\begin{abstract}
This research-based paper aimed at assessing the impact of COVID-19 on teaching and learning in public secondary schools in South-West Nigeria. It described the socio-demographic characteristics of the respondents; assessed COVID-19 prevalence in the schools; examined its impact on teaching and learning; examined alternative teaching and learning strategies (ATLS) employed; identified teachers' challenges in using the ATLS; and determined ATLS effectiveness in the schools. Building on the transformative learning theory, a descriptive survey research design and the multi-stage sampling procedure were employed to select a sample of 930 respondents (30 principals, 300 senior school teachers, and 600 students of Grade 11 and Grade 12 classes) for the study. Data were collected using a 5-point-Likert scale questionnaire with Cronbach's alpha reliability coefficient of 0.86 . Data were analyzed with descriptive statistics and weighted means. The results showed the prevalence of COVID-19 with negative impact on students who did not have access to traditional face-to-face classroom learning, while virtual online classes limited the subjects usually taught. The ATLS employed are TV \& Radio, Zoom, Google Classroom, WhatsApp Group, Microsoft Team and Google Chat, and teachers' challenges in using ATLS include: unequal access to ICT-based learning, and lack of Internet facilities and connectivity, and they were not effective. It was concluded that the outbreak of the COVID-19 impacted negatively on teaching and learning in public secondary schools in South-West Nigeria, and appropriate online strategies should be provided to address this challenge.
\end{abstract}

Keywords: coronavirus, teaching and learning platform, public secondary schools

DOI: $10.7176 / \mathrm{JEP} / 13-6-05$

Publication date: February $28^{\text {th }} 2022$

\section{Introduction}

The coronavirus (COVID-19) pandemic has spread across the globe with over 236 million cases and a fatality rate of 4,831,486 recorded (WHO, 2020) and affecting socio-economic life of people and the school system. The increasing spread of the virus has been adduced to the symptomatic and asymptomatic nature of the disease, and the failure to identify and properly manage both cases by testing or screening the population (Bai et al., 2020; Addi et al., 2020). This has placed more than one-third of the entire world population under some form of restriction such as national quarantines, border closures, online work, and school closures to reduce the spread of the disease, and has equally affected the economy of many nations.

In Nigeria, the advent of COVID-19 on 11th March 2020, and the categorization of the country as one of the 13 vulnerable and high-risk African countries, led to imposing an immediate ban on international travels, lockdown of the nation's economy, and closure of all institutions of learning by the Federal Ministry of Education with the abrupt discontinuation of the face-to-face teaching and learning method on March 19, 2020 (Marbot, 2020; Nleblem, 2020). Presently, 206920 cases of COVID-19 have been confirmed, 194651 cases discharged, and 2740 deaths recorded in the 36 states of Nigeria and the Federal Capital Territory. States in South-West Nigeria were among those listed with a high increasing number of cases (NCDC, 2021).

Building on the transformative learning theory of Mezirow (1997) that learning experiences induces and shape the learner to produce a significant impact, or paradigm shift, that affects the learner's subsequent experiences, the unexpected, unplanned, and sudden shutdown of schools has a huge effect on all stakeholders, including students, teachers, parents, and the nation as a whole. According to The Education Partnership and Nigerian Economic Summit Group (TEP and NESG, 2020), about 80\% of government officials in 22 states and the Federal Capital Territory claimed that the pandemic has negatively affected children's learning and wellbeing, disrupted normal academic and extra-curricular activities with the suspension of face-to-face learning, and disrupted internal and external examinations. For example, public examinations such as the West African Senior School Certificate Examination (WASSCE) and National Examination Council for Senior Secondary School Certificate (NECO SSC) were postponed, while students, teachers, and principals were under severe stress and anxiety arising from school closure. Fakoya (2020) stated that cases of neglect, sexual abuse and gender-based violence, rape, drug abuse were also likely to increase among the secondary school students, with the risk of students drop-out while some others may have been engaged in a business that is fetching them money and so may be reluctant to return to school even when the schools reopen. The lock-down also interrupted learning for 
vulnerable children and caused socio-economic problems to approximately $61 \%$ of the Nigerian population who could not go to work, leading to wage loss, low productivity and poverty (NBS, 2020).

In addressing the challenges of school shut-down, UNESCO (2020) and UNICEF (2020) recommended the use of distance learning programmes and open educational platforms that schools can use to reach learners remotely to limit the disruption of education in the country. Thus, stakeholders in education have been making efforts to promote continued learning through these media to bridge the potential learning gaps in secondary school education. According to Vegas (2020), about $90 \%$ of the high-income countries provide remote learning opportunities while less than $25 \%$ of the low-income countries offer such opportunities to their learners. Only about $23 \%$ of countries in sub-Saharan Africa combine online and broadcast media platforms while only $11 \%$ rely exclusively on online platforms to engage their learners. Though some state governments in Nigeria such as Lagos, Ogun, Osun, Ondo and Ekiti introduced television and radio teaching and learning platforms, a larger number $(70 \%)$ could not meet up with the learning needs of their students, as the socio-economic status of most parents, the high cost of data and the epileptic state of electricity supply in the country constituted a barrier for many students to access the platform maximally (Henry and Agbadi, 2020; Ogunode, 2020). Teaching via the radio that seems to have a wider coverage compared to other outlets has its challenges because not all the subjects can be effectively taught due to learner's state of mind, their different learning environments, students' learning styles, and the time taken to understand what is being transmitted. Only students in the private secondary schools had the privilege of continuing with their learning virtually. In addition, students' inaccessibility to technological platforms, digital tools and traditional media result in creating a pool of young adults who may never catch up and thereby create a learning gap long after the pandemic is over (Amorighoye, 2020).

According to Obiakor and Adeniran (2020) \& TEP and NESG (2020), 75\% of respondents claimed that lack of resources for learners is a huge challenge for remote learning in Nigeria, as children whose parents cannot afford remote learning facilities have to wait for school to re-open to continue learning. Also, $84 \%$ of government officials claimed that their states provided some alternative teaching-learning strategies (ATLS) ranging from large-scalelow-tech solutions that do not require internet-enabled devices (radio and television) to high-tech alternatives (virtual classrooms, video conferencing, animated lessons, and online resource libraries) that require internetenabled devices during the pandemic (TEP \& NESG, 2020). Furthermore, $49 \%$ of the respondents claimed that internet-based learning platforms were created for students with such educational resources as Webinar, Zoom, Google classroom, WhatsApp Voice Note, among others. Many schools, therefore, implemented their distance learning contingency plans and connected students and teachers through online platforms and tools such as the Mobile Classroom; WAEC E-Learning Tool Kit; Unity Schools Virtual Learning Platforms and Khan Academy. The Federal, State and Local governments are now partnering with broadcasting service providers to deliver educational content via television and radio during dedicated hours, while teachers and parents have had to quickly adapt to teaching in this new reality to ensure that students engage in learning.

Digital 2020 Global Overview Report shows that $58 \%$ of Nigerians are not connected to the internet while students are constrained in accessing the textbooks and reading materials for learning. Other learning strategies for bridging the gaps of academic disruption include: attending summer school and visiting libraries as home and evening lessons were not available during the lock-down, sending reading and writing materials home to children, and daily reading practice through radio broadcasts. Teachers and upper-level students can also act as virtual tutors using simple short message services (SMS) platforms to enhance the effectiveness of online and radio broadcast programmes. Thus, children learning was a challenge facing education leaders globally as a result of the pandemic (UNICEF, 2020).

Nonetheless, evidence on the effectiveness of the ATLS employed during the school shutdown to keep the learning going in public secondary schools in South-West Nigeria is limited, because many of these interventions have been adopted as immediate responses to the crisis without prior large-scale implementation. It has been a challenge facilitating practical-oriented subjects that typically engaged a large number of students through laboratory experiments. Only very few schools can afford to set up and maintain virtual science laboratories where students and teachers can work together to simulate experiments (Abbey and Hoxley, 2020). Hence, assessing the impact of the COVID-19 pandemic in schools becomes imperative.

\subsection{Statement of the Problem}

The outbreak of Coronavirus in Nigeria without any doubt has adversely affected the economic, agricultural, political, religious, social, transportation and educational systems of the nation. The National Centre for Disease Control (NCDC, 2020) reported that an estimate of 46 million students have been forced to stay at home in Nigeria, while, cases of COVID-19 keep increasing by the day in various states including those in South-West Nigeria. Teaching and learning have therefore been adversely affected in schools due to the government's lockdown pronouncement without any concrete alternative arrangement for the teachers and students. Most public-school students are therefore experiencing disruption in their learning because the schools are not well equipped with an alternative learning platform like ICT infrastructural facilities. In addition, the students cannot afford remote 
learning resources at home while the students, teachers and parents are under stress and anxiety as to what becomes of their future with possible students' drop out due to prolonged school shut-down. This raises the following research questions: What socio-demographic characteristics do students, teachers and principals exhibit in public secondary schools in South-West Nigeria during the COVID-19 pandemic? What is the prevalence of the COVID19 in the schools? How does the COVID-19 pandemic impact teaching and learning in schools? What alternative teaching and learning strategies (ATLS) were employed in schools during the shutdown? What are the challenges faced in utilizing the ATLS? and How effective were the ATLS to teaching and learning in the schools?

Though there are general studies on the impact of Coronavirus disease on the educational sector, there are limited studies specific to public secondary school education, particularly in South-West Nigeria. This study aimed at filling this knowledge gap.

\subsection{Objectives of the Study}

The main objective of the study was to assess the impact of the COVID-19 pandemic on teaching and learning in public secondary schools in South-West Nigeria, to improve education in Nigeria. Specifically, the study sought to describe the socio-demographic characteristics of students, teachers and principals in the public secondary school in South West Nigeria; examine the prevalence of COVID-19 in the schools; assess the impact of COVID19 on teaching and learning in the schools; examine the alternative teaching and learning strategies (ATLS) employed in the schools; identify the challenges of students, teachers and principals in utilizing the ATLS in the schools; and determine the effectiveness of the ATLS on teaching and learning in the schools.

\subsection{Study Hypotheses}

The two null hypotheses tested are Ho ${ }_{1}$ : COVID-19 has no significant effect on public secondary school education in South-West Nigeria; $\mathrm{Ho}_{2}$ : There is no significant difference in students, teachers and principals' assessment of the effectiveness of ATLS employed in the schools.

\section{Research Approach}

A descriptive survey research design was used for the study. The population consisted of the principals, teachers and students of senior secondary schools, and a multistage sampling procedure was used to select respondents for the study. Three states (Ekiti, Osun \& Oyo) were purposely selected out of the six (6) states in South-West Nigeria. Five (5) local government areas (LGAs) and two (2) schools per LGA were randomly selected in each state. In each school, ten (10) teachers and twenty (20) students were purposively selected from among the Grade 11 and Grade 12 classes only, to give a total of 100 teachers and 200 students per state while the principal of each school was purposively selected for the study, giving a total of 930 respondents comprising 30 principals, 300 teachers of students in Grades $11 \& 12$ classes, and 600 students of Grade $11 \& 12$ classes.

Both quantitative and qualitative approaches were used in data collection by use of questionnaires, interview guides and document analysis checklists. Data were collected using a 5-point-Likert scale questionnaire ranging from Strongly Disagree $(S D)=1$, Disagree $(D)=2$, Neutral $(N)=3$, Agree $(A)=4$, to Strongly Agree $(S A)=5$. The questionnaire was subjected to content validity by experts in the Test and Measurement Department of Obafemi Awolowo University, Nigeria while its reliability was established using two schools outside the scope of the study. Cronbach's alpha was used to determine the reliability coefficient of 0.86 . Data were analyzed using both descriptive statistics (frequency counts and percentages) and weighted means.

\section{Findings and Discussion}

3.1 The Socio-demographic Characteristics of Respondents

The socio-demographic characteristics of respondents in this study are shown in Table 1. 
Table 1: Sociodemographic Characteristics of Respondents

\begin{tabular}{|c|c|c|c|c|c|c|}
\hline \multirow[t]{3}{*}{ Characteristics } & & & \multicolumn{2}{|l|}{ Respondents } & \multirow{2}{*}{\multicolumn{2}{|c|}{ Principals }} \\
\hline & \multicolumn{2}{|c|}{ Students } & \multicolumn{2}{|c|}{ Teachers } & & \\
\hline & $(n=600)$ & $\%$ & $(n=300)$ & $\%$ & $(n=30)$ & $\%$ \\
\hline \multicolumn{7}{|l|}{ Gender } \\
\hline Male & 268 & 44.7 & 148 & 51.0 & 14 & 46.7 \\
\hline Female & 329 & 54.8 & 138 & 47.6 & 14 & 46.7 \\
\hline NR & 3 & 0.5 & 4 & 1.4 & 2 & 6.7 \\
\hline \multicolumn{7}{|l|}{ Age Range (years) } \\
\hline $10-20$ & 587 & 97.8 & 8 & 2.8 & - & - \\
\hline $21-30$ & 13 & 2.2 & 8 & 2.8 & - & - \\
\hline $31-40$ & - & - & 194 & 66.9 & 2 & 6.7 \\
\hline $41-50$ & - & - & 66 & 22.8 & 1 & 3.3 \\
\hline More than 50 & - & - & 10 & 3.4 & 25 & 83.3 \\
\hline NR & - & - & 4 & 1.4 & 2 & 6.7 \\
\hline Mean (Std. Dev.) & \multicolumn{2}{|c|}{$12.1(0.68)$} & \multicolumn{2}{|c|}{$40.1(0.28)$} & \multicolumn{2}{|c|}{$58.4(2.33)$} \\
\hline \multicolumn{7}{|l|}{ Discipline } \\
\hline Science & 254 & 42.3 & - & - & - & - \\
\hline Arts & 95 & 15.8 & - & - & - & - \\
\hline Social Sciences & 251 & 41.8 & - & - & - & - \\
\hline \multicolumn{7}{|l|}{ Marital Status } \\
\hline Single & - & - & 10 & 3.4 & - & - \\
\hline Married & - & - & 256 & 88.3 & 21 & 70.0 \\
\hline Divorced & - & - & 21 & 7.2 & 9 & 30.0 \\
\hline Widower & - & - & 2 & 0.7 & - & - \\
\hline NR & - & - & 1 & 0.3 & - & - \\
\hline \multicolumn{7}{|c|}{ Educational Qualification } \\
\hline First Degree & - & - & 275 & 94.8 & 8 & 26.7 \\
\hline Master Degree & - & - & 10 & 3.4 & 21 & 70.0 \\
\hline PhD. & - & - & 2 & 0.7 & 1 & 3.3 \\
\hline NR & - & - & 3 & 1.0 & - & - \\
\hline \multicolumn{7}{|c|}{ Number of Years in Service } \\
\hline $1-10$ & - & - & 131 & 45.2 & - & - \\
\hline $11-20$ & - & - & 151 & 52.1 & 1 & 3.3 \\
\hline $21-30$ & - & - & 5 & 1.7 & 22 & 73.3 \\
\hline More than 30 & - & - & 2 & 0.7 & 7 & 23.3 \\
\hline NR & - & - & 1 & 0.3 & - & - \\
\hline Mean (Std. Dev.) & & & $12.6(1.75)$ & 26 & $(2.31)$ & \\
\hline
\end{tabular}

\section{$N R=$ No Response (Missing)}

From Table 1 , about $45 \%, 51 \%$ and $47 \%$ of the students, teachers and principal respectively were male, $55 \%$, $48 \%$, and $47 \%$ were female, while $0.5 \%, 1.4 \%$ and $6.7 \%$ respectively did not respond to their gender. Majority of the students $(97.8 \%)$ were in the age range of $10-20$ years, $66.9 \%$ of teachers were in the $31-40$ age bracket, while a larger percentage of the principals were in the 41-50 years age bracket. The mean and standard deviation were $12.1(0.68)$ for students, $40.1(0.28)$ for teachers, and 58.4 (2.33) for principals. The distribution of students showed that $42.3 \%$ were in the Science class, $41.8 \%$ in Social Sciences and $15.8 \%$ were in Arts class. While all the students were single, most teachers $(88.3 \%)$ and principals $(70 \%)$ were married. However, $7.2 \%$ and $30.0 \%$ of teachers and principals respectively were divorcees, while only $0.7 \%$ of the teachers were widowers.

A larger percentage (94.8\%) of the teachers had a first-degree certificate, $70.0 \%$ had a Master's degree while only $3.3 \%$ had a PhD. Furthermore, $52.1 \%$ of the teachers have been in service for between 11 and 20 years while $45.2 \%$ have been in service between 1 and 10 years.

The majority of principals (73.3\%) have been in service for between $21-30$ years while $23.3 \%$ of them have spent more than 30 years. The mean and standard deviation of the teachers and principals were $12.6(1.75)$ and $26.4(2.31)$, respectively.

\subsection{The Prevalence of COVID-19 in the Public Secondary Schools}

The higher weighted mean (3.90) against the criterion mean (3.00) suggests that COVID-19 is prevalent in SouthWest Nigeria (Table 2). Responses to individual items showed that $88.6 \%$ of the respondents agreed that COVID- 
19 is real in their states, $75.9 \%$ rated the fatality as high, while $68.8 \%$ indicated that its transmission is very high. Generally, $73.8 \%$ of the respondents agreed that their state is vulnerable due to the relatively large population and concentration of people at marketplaces and social events. This corroborates the report of the NCDC (2021) stating the total confirmed cases to be over 236 million people as of October 8, 2021, and over 4.8 million deaths, with Lagos state having the highest number of cases.

Table 2: Prevalence of COVID-19 in the Public Secondary Schools

\begin{tabular}{|c|c|c|c|c|c|c|c|c|c|c|c|c|}
\hline \multirow[t]{2}{*}{ Items } & \multicolumn{2}{|c|}{ SD } & \multicolumn{2}{|c|}{ D } & \multicolumn{2}{|c|}{$\mathbf{N}$} & \multicolumn{2}{|c|}{$\mathbf{A}$} & \multicolumn{2}{|c|}{ SA } & \multirow[b]{2}{*}{ Mean } & \multirow[b]{2}{*}{ SD } \\
\hline & $\mathrm{n}$ & $\%$ & $\mathrm{n}$ & $\%$ & $\mathrm{n}$ & $\%$ & $\mathrm{n}$ & $\%$ & $\mathrm{n}$ & $\%$ & & \\
\hline $\begin{array}{l}\text { Covid-19 is real in my } \\
\text { state. }\end{array}$ & 40 & 4.3 & 21 & 2.3 & 44 & 4.8 & 198 & 21.5 & 617 & 67.1 & 4.5 & 1.0 \\
\hline $\begin{array}{l}\text { The fatality rate of Covid- } \\
19 \text { is high in my state. }\end{array}$ & 54 & 5.9 & 113 & 12.3 & 55 & 6.0 & 621 & 67.5 & 77 & 8.4 & 3.6 & 1.0 \\
\hline $\begin{array}{l}\text { The propensity for Covid- } \\
19 \text { transmission is very } \\
\text { high in my state. }\end{array}$ & 71 & 7.7 & 98 & 10.7 & 118 & 12.8 & 94 & 10.2 & 539 & 58.6 & 4.0 & 1.4 \\
\hline $\begin{array}{l}\text { My state is one of the } \\
\text { vulnerable states to } \\
\text { COVID-19 in Nigeria. }\end{array}$ & 65 & 7.1 & 114 & 12.4 & 62 & 6.7 & 617 & 67.1 & 62 & 6.7 & 3.5 & 1.0 \\
\hline
\end{tabular}

\subsection{Impact of COVID-19 on Teaching and Learning in the Schools}

The results of the impact of COVID-19 on teaching and learning in the schools showed that $87.3 \%(23.3+64.0)$ of the students agreed that the pandemic has increased their desire for online teaching and learning (Table 3 ). This is corroborated by the higher weighted mean of 3.85 recorded against the criterion mean of 3.00 .

From Table 3, $82 \%$ of the students supported by a weighted mean of 3.73 suggested that their desire to learn at home has increased. About $83 \%$ with a weighted mean of 4.28 claimed that virtual class does not take care of all the subjects taught in school $(\bar{x}=4.28) ; 85.5 \%$ indicated that face-to-face teaching and learning was disrupted $(\bar{x}=4.20) ; 76.1 \%$ claimed that the students have no access to their teachers $(\bar{x}=4.15) ; 76.1 \%$ agreed that students do not have access to normal classroom environment $(\bar{x}=4.12) ; 79.9 \%$ reported that students have no access to their peers $(\bar{x}=3.94), 85.4 \%$ agreed that they do have access to a normal classroom environment, and a relatively larger percentage $(88.4 \%)$ claimed that school shutdown has a psychological and emotional effect on them $(\bar{x}=3.88)$. However, only $26.7 \%$ of the students agreed that their reading culture has greatly increased $(\bar{x}$ $=2.66$ ) while $35.8 \%$ with a weighted mean of 2.66 claimed that school shutdown affected students' promotion or placement in the schools.

Table 3: Impact of COVID-19 on Teaching and Learning in the Public Secondary Schools

\begin{tabular}{|c|c|c|c|c|c|c|c|c|c|c|c|c|}
\hline \multirow[t]{2}{*}{ Items } & \multicolumn{2}{|l|}{ SD } & \multicolumn{2}{|l|}{ D } & \multicolumn{2}{|l|}{$\mathbf{N}$} & \multicolumn{2}{|l|}{$\mathbf{A}$} & \multicolumn{2}{|l|}{ SA } & \multirow[b]{2}{*}{ Mean } & \multirow[b]{2}{*}{ SD } \\
\hline & $\mathrm{n}$ & $\%$ & $\mathrm{n}$ & $\%$ & $\mathrm{n}$ & $\%$ & $\mathrm{n}$ & $\%$ & $\mathrm{n}$ & $\%$ & & \\
\hline $\begin{array}{l}\text { COVID-19 pandemic has } \\
\text { increased my desire for online } \\
\text { teaching and learning. }\end{array}$ & 31 & 3.4 & 45 & 4.9 & 41 & 4.5 & 214 & 23.3 & 589 & 64.0 & 4.4 & 1.0 \\
\hline $\begin{array}{l}\text { Students' desire to learn at } \\
\text { home has increased. }\end{array}$ & 40 & 4.3 & 85 & 9.2 & 41 & 4.5 & 673 & 73.2 & 81 & 8.8 & 3.7 & 0.9 \\
\hline $\begin{array}{l}\text { Students' reading culture has } \\
\text { greatly increased. }\end{array}$ & 46 & 5.0 & 567 & 61.6 & 61 & 6.6 & 142 & 15.4 & 104 & 11.3 & 2.7 & 1.2 \\
\hline $\begin{array}{l}\text { Virtual class does not take care } \\
\text { of all the subjects taught in } \\
\text { school. }\end{array}$ & 37 & 4.0 & 65 & 7.1 & 57 & 6.2 & 210 & 22.8 & 551 & 59.9 & 4.3 & 1.1 \\
\hline $\begin{array}{l}\text { School shutdown has } \\
\text { psychological and emotional } \\
\text { effect on me }\end{array}$ & 35 & 3.8 & 31 & 3.4 & 40 & 4.3 & 718 & 78.0 & 96 & 10.4 & 3.9 & 0.8 \\
\hline $\begin{array}{l}\text { Pubic secondary } \text { school } \\
\text { students have no access to } \\
\text { face-to-face } \\
\text { learning. }\end{array}$ & 40 & 4.3 & 72 & 7.8 & 25 & 2.7 & 165 & 17.9 & 618 & 67.2 & 4.4 & 1.1 \\
\hline
\end{tabular}




\begin{tabular}{|c|c|c|c|c|c|c|c|c|c|c|c|c|}
\hline \multirow[t]{2}{*}{ Items } & \multicolumn{2}{|l|}{ SD } & \multicolumn{2}{|l|}{ D } & \multicolumn{2}{|l|}{$\mathbf{N}$} & \multicolumn{2}{|l|}{$\mathbf{A}$} & \multicolumn{2}{|l|}{ SA } & \multirow[b]{2}{*}{ Mean } & \multirow[b]{2}{*}{ SD } \\
\hline & $\mathrm{n}$ & $\%$ & $\mathrm{n}$ & $\%$ & $\mathrm{n}$ & $\%$ & $\mathrm{n}$ & $\%$ & $\mathrm{n}$ & $\%$ & & \\
\hline $\begin{array}{l}\text { Public secondary school } \\
\text { students have no access to } \\
\text { their teachers. }\end{array}$ & 46 & 5.0 & 98 & 10.7 & 76 & 8.3 & 153 & 16.6 & 547 & 59.5 & 4.2 & 1.2 \\
\hline $\begin{array}{l}\text { Public secondary school } \\
\text { students have no access to } \\
\text { their peers. }\end{array}$ & 80 & 8.7 & 69 & 7.5 & 36 & 3.9 & 378 & 41.1 & 357 & 38.8 & 3.9 & 1.2 \\
\hline $\begin{array}{l}\text { Face to face teaching and } \\
\text { learning was disrupted. }\end{array}$ & 41 & 4.5 & 64 & 7.0 & 28 & 3.0 & 325 & 35.3 & 462 & 50.2 & 4.2 & 1.1 \\
\hline $\begin{array}{l}\text { No access to a normal } \\
\text { classroom environment. }\end{array}$ & 58 & 6.3 & 63 & 6.8 & 13 & 1.4 & 367 & 39.9 & 419 & 45.5 & 4.1 & 1.1 \\
\hline $\begin{array}{l}\text { School shutdown has effect on } \\
\text { students' promotion or } \\
\text { placement in schools }\end{array}$ & 213 & 23.2 & 343 & 37.3 & 34 & 3.7 & 201 & 21.8 & 129 & 14.0 & 2.7 & 1.4 \\
\hline
\end{tabular}

\subsection{The Alternative Teaching and Learning Strategies Used during Schools' Shutdown}

The results of ATLS employed by the government in the schools during the schools' shutdown showing a lower weighted mean of 2.56 against the criterion mean of 3.00 suggests that apart from the provision of Zoom $(x=3.44)$ and TV \& Radio $(x=4.56)$ with a relatively larger percentage of respondents $(69.4 \%$ and $90.4 \%$ respectively $)$, respondents' general assessment of the use of most of the ATLS listed were below acceptability level (Table 4).

The ratings of the other strategies were: WhatsApp Group Discussion $(\bar{x}=2.37)$, Google Classroom $(\bar{x}=2.46)$, Google chat $(\bar{x}=1.64)$, Microsoft Team $(\bar{x}=1.84)$ and Google docs $(\bar{x}=1.69)$ were below the criterion of acceptability of 3.00. Therefore, the two highly rated ATLS employed by the government in the public secondary schools in South-West Nigeria is the Zoom and TV\& Radio platforms. This agrees with the findings of Henry and Agbadi (2020) \& Ogunode, (2020) that some state governments such as Lagos, Ogun, Osun, Ondo and Ekiti introduced television and radio teaching and learning while a large number $(70 \%)$ of the states across the country could not do anything to meet up with the learning needs of their students.

Table 4: Alternative Teaching and Learning Strategies Used in the Public Secondary Schools

\begin{tabular}{|c|c|c|c|c|c|c|c|c|c|c|c|c|}
\hline \multirow[t]{2}{*}{ Items } & \multicolumn{2}{|c|}{ SD } & \multicolumn{2}{|c|}{ D } & \multicolumn{2}{|c|}{$\mathbf{N}$} & \multicolumn{2}{|c|}{$\mathbf{A}$} & \multicolumn{2}{|c|}{ SA } & \multirow[t]{2}{*}{ Mean } & \multirow[t]{2}{*}{ SD } \\
\hline & $\mathrm{n}$ & $\%$ & $\mathrm{n}$ & $\%$ & $\mathrm{n}$ & $\%$ & $\mathrm{n}$ & $\%$ & $\mathrm{n}$ & $\%$ & & \\
\hline $\begin{array}{l}\text { Alternative teaching and } \\
\text { learning strategy provided } \\
\text { by the government was- } \\
\text { WhatsApp Group } \\
\text { Discussion. }\end{array}$ & 251 & 27.3 & 376 & 40.9 & 52 & 5.7 & 180 & 19.6 & 61 & 6.6 & 2.37 & 1.25 \\
\hline $\begin{array}{lc}\text { The alternative } & \text { teaching } \\
\text { and learning } & \text { strategy } \\
\text { provided was- } & \text { Google } \\
\text { Classroom } & \end{array}$ & 69 & 7.5 & 566 & 61.5 & 106 & 11.5 & 151 & 16.4 & 28 & 3.0 & 2.46 & 0.95 \\
\hline $\begin{array}{l}\text { The alternative teaching } \\
\text { and learning strategy } \\
\text { provided was- Zoom. }\end{array}$ & 100 & 10.9 & 118 & 12.8 & 63 & 6.8 & 555 & 60.3 & 84 & 9.1 & 3.44 & 1.16 \\
\hline $\begin{array}{l}\text { The alternative teaching } \\
\text { and learning strategy } \\
\text { provided was- Google chat }\end{array}$ & 627 & 68.2 & 116 & 12.6 & 86 & $\begin{array}{l}9.3 \\
\end{array}$ & 64 & 7.0 & 27 & 2.9 & 1.64 & 1.09 \\
\hline $\begin{array}{l}\text { The alternative teaching } \\
\text { and learning strategy } \\
\text { provided was- Microsoft } \\
\text { Team. }\end{array}$ & 462 & 50.2 & 268 & 29.1 & 88 & 9.6 & 79 & 8.6 & 23 & 2.5 & 1.84 & 1.07 \\
\hline $\begin{array}{l}\text { The alternative teaching } \\
\text { and learning strategy } \\
\text { provided was-Google docs }\end{array}$ & 629 & 68.4 & 83 & 9.0 & 100 & 10.9 & 79 & 8.6 & 29 & 3.2 & 1.69 & 1.15 \\
\hline
\end{tabular}




\begin{tabular}{|c|c|c|c|c|c|c|c|c|c|c|c|c|}
\hline \multirow[t]{2}{*}{ Items } & \multicolumn{2}{|c|}{ SD } & \multicolumn{2}{|c|}{ D } & \multicolumn{2}{|c|}{$\mathbf{N}$} & \multicolumn{2}{|c|}{$\mathbf{A}$} & \multicolumn{2}{|c|}{ SA } & \multirow[t]{2}{*}{ Mean } & \multirow[t]{2}{*}{ SD } \\
\hline & $\mathrm{n}$ & $\%$ & $\mathrm{n}$ & $\%$ & $\mathrm{n}$ & $\%$ & $\mathrm{n}$ & $\%$ & $\mathrm{n}$ & $\%$ & & \\
\hline $\begin{array}{l}\text { The alternative teaching } \\
\text { and learning strategy } \\
\text { provided was- T.V and } \\
\text { Radio platforms. }\end{array}$ & 25 & 2.7 & 29 & 3.2 & 34 & 3.7 & 149 & 16.2 & 683 & 74.2 & 4.56 & 0.92 \\
\hline $\begin{array}{l}\text { Other teaching and } \\
\text { learning platforms were } \\
\text { provided by government. }\end{array}$ & 245 & 26.6 & 376 & 40.9 & 51 & 5.5 & 144 & 15.7 & 104 & 11.3 & 2.44 & 1.33 \\
\hline
\end{tabular}

\subsection{Challenges in Utilizing the Alternative Teaching and Learning Strategies in the Schools}

The challenges encountered in utilizing the alternative learning strategies in public secondary schools are shown in Table 5.

From Table 5, the weighted mean (3.79) obtained against the criterion mean (3.00) shows that all the prevailing conditions listed are challenges faced by the respondents. These include serious challenges as indicated by $89.4 \%$ of respondents agreeing to unequal access to ICT-based learning; $87.4 \%$ claimed lack of internet facilities; $86.5 \%$ indicated no regular supply of electricity at home during online classes; $85.9 \%$ claimed data supply was not made available to students for online teaching and learning; $84.5 \%$ indicated that students have no access to online materials at home; $82.4 \%$ agreed that the students have no access to internet facilities; $82.1 \%$ claimed that teachers find the online teaching method more difficult than face-to-face learning; $81.7 \%$ agreed that students have no access to internet-enabled devices to aid their learning; $79.1 \%$ agreed that teachers have no training on how to use technology to facilitate teaching; $78.5 \%$ claimed that every public secondary school has no internet connectivity services; $78.2 \%$ agreed that teachers have no pre-knowledge of online teaching; $77.7 \%$ claimed that teachers have no access to remote teaching equipment such as computer, android phone, iPhone and iPad; and $75.9 \%$ agreed that teachers find it difficult using the technology to facilitate learning. However, only $9 \%$ and $28.5 \%$ of the respondents had a weighted mean of 1.58 and 2.67 respectively lesser than the criterion mean (3.00), suggesting that access to Radio \& TV by teachers and students are not too serious a challenge in public secondary schools.

Henry and Agbadi (2020) \& Ogunode (2020) corroborated these findings that the epileptic state of electricity supply in the country, the socio-economic status of most parents, and the high cost of data constituted a barrier for students' access to teaching maximally on the radio and television provided by some state governments.

Table 5: Challenges of Utilizing the Alternative Learning Strategies in Public Secondary Schools in South-West Nigeria

\begin{tabular}{|c|c|c|c|c|c|c|c|c|c|c|c|c|}
\hline \multirow[b]{2}{*}{ Items } & \multicolumn{2}{|c|}{ SD } & \multicolumn{2}{|c|}{ D } & \multicolumn{2}{|c|}{$\mathbf{N}$} & \multicolumn{2}{|c|}{$\mathbf{A}$} & \multicolumn{2}{|c|}{ SA } & \multirow[b]{2}{*}{ Mean } & \multirow[b]{2}{*}{ SD } \\
\hline & $\mathrm{n}$ & $\%$ & $\mathrm{n}$ & $\%$ & $\mathrm{n}$ & $\%$ & $\mathrm{n}$ & $\%$ & $\mathrm{n}$ & $\%$ & & \\
\hline Lack of internet facilities. & 32 & 3.5 & 36 & 3.9 & 43 & 4.7 & 195 & 21.2 & 614 & 66.7 & 4.4 & 1.0 \\
\hline $\begin{array}{l}\text { Unequal access to ICT- } \\
\text { based learning. }\end{array}$ & 29 & 3.2 & 40 & 4.3 & 28 & 3.0 & 199 & 21.6 & 624 & 67.8 & 4.5 & 1.9 \\
\hline $\begin{array}{l}\text { There is no regular supply of } \\
\text { electricity at home during } \\
\text { online classes }\end{array}$ & 37 & 4.0 & 37 & 4.0 & 50 & 5.4 & 391 & 42.5 & 405 & 44.0 & 4.2 & 0.9 \\
\hline $\begin{array}{l}\text { Every student has no access } \\
\text { to online materials at home }\end{array}$ & 25 & 2.7 & 61 & 6.6 & 57 & 6.2 & 368 & 40.0 & 409 & 44.5 & 4.2 & 0.9 \\
\hline $\begin{array}{l}\text { Teachers find it very } \\
\text { difficult using the } \\
\text { technology to facilitate } \\
\text { learning. }\end{array}$ & 39 & 4.2 & 80 & 8.7 & 103 & 11.2 & 597 & 64.9 & 101 & 11.0 & 3.7 & 1.3 \\
\hline $\begin{array}{l}\text { Teachers find the online } \\
\text { teaching method more } \\
\text { difficult than face-to- face } \\
\text { learning. }\end{array}$ & 35 & 3.8 & 77 & 8.4 & 53 & 5.8 & 448 & 48.7 & 307 & 33.4 & 3.9 & 1.0 \\
\hline $\begin{array}{l}\text { Teachers have no pre- } \\
\text { knowledge of } \\
\text { teaching. }\end{array}$ & 53 & 5.8 & 83 & 9.0 & 64 & 7.0 & 428 & 46.5 & 292 & 31.7 & 3.9 & 1.1 \\
\hline $\begin{array}{l}\text { Public secondary school } \\
\text { students have no access to } \\
\text { internet facilities. }\end{array}$ & 55 & 6.0 & 72 & 7.8 & 35 & 3.8 & 330 & 35.9 & 428 & 46.5 & 4.1 & 1.2 \\
\hline
\end{tabular}




\begin{tabular}{|c|c|c|c|c|c|c|c|c|c|c|c|c|}
\hline \multirow[b]{2}{*}{ Items } & \multicolumn{2}{|c|}{ SD } & \multicolumn{2}{|c|}{ D } & \multicolumn{2}{|c|}{$\mathbf{N}$} & \multicolumn{2}{|c|}{$\mathbf{A}$} & \multicolumn{2}{|c|}{ SA } & \multirow[b]{2}{*}{ Mean } & \multirow[b]{2}{*}{ SD } \\
\hline & $\mathrm{n}$ & $\%$ & $\mathrm{n}$ & $\%$ & $\mathrm{n}$ & $\%$ & $\mathrm{n}$ & $\%$ & $\mathrm{n}$ & $\%$ & & \\
\hline $\begin{array}{l}\text { Data supply was not made } \\
\text { available to students for } \\
\text { online teaching } \\
\text { learning. }\end{array}$ & 38 & 4.1 & 66 & 7.2 & 25 & 2.7 & 383 & 41.6 & 408 & 44.3 & 4.2 & 1.1 \\
\hline $\begin{array}{l}\text { Teachers have no training } \\
\text { on how to use technology to } \\
\text { facilitate teaching. }\end{array}$ & 57 & 6.2 & 80 & 8.7 & 55 & 6.0 & 610 & 66.3 & 118 & 12.8 & 3.7 & 1.0 \\
\hline $\begin{array}{l}\text { Teachers have no access to } \\
\text { radio and television sets. }\end{array}$ & 650 & 70.7 & 122 & 13.3 & 66 & 7.2 & 52 & 5.7 & 30 & 3.3 & 1.6 & 1.1 \\
\hline $\begin{array}{l}\text { Students have access to } \\
\text { radio and television sets. }\end{array}$ & 45 & 4.9 & 573 & 62.3 & 40 & 4.3 & 163 & 17.7 & 99 & 10.8 & 2.7 & 1.2 \\
\hline $\begin{array}{l}\text { Teachers have no access to } \\
\text { remote-teaching equipment } \\
\text { such as computers, Android } \\
\text { Phones, iPhone and iPad. }\end{array}$ & 55 & 6.0 & 97 & 10.5 & 53 & 5.8 & 587 & 63.8 & 128 & 13.9 & 3.7 & 1.0 \\
\hline $\begin{array}{l}\text { Students have no access to } \\
\text { internet- enabled devices to } \\
\text { aid their learning. }\end{array}$ & 67 & 7.3 & 64 & 7.0 & 38 & 4.1 & 595 & 64.7 & 156 & 17.0 & 3.8 & 1.1 \\
\hline $\begin{array}{l}\text { Every public secondary } \\
\text { school has no connection to } \\
\text { internet services. }\end{array}$ & 55 & 6.0 & 74 & 8.0 & 69 & 7.5 & 150 & 16.3 & 572 & 62.2 & 4.2 & 1.3 \\
\hline
\end{tabular}

According to the National Bureau of Statistics report (NBS, 2020), approximately $61 \%$ of the Nigerian population live in extreme poverty. Teaching via the radio that seems to have a wider coverage compared to other outlets, has its demerit because not all subjects can be effectively taught via this medium as learning can be inhibited due to the learner's state of mind, the different learning environment of learners, the learning styles of students, and the time it takes to understand what is being transmitted. Similarly, Obiakor and Adeniran (2020) reported that children whose parents cannot afford remote learning facilities may have to wait for school to reopen to continue learning. Thus, the number of learners that will eventually return to school when the pandemic is over is not certain.

\subsection{Effectiveness of the Alternative Teaching and Learning Strategies in the Schools}

Results in Table 6 show the effectiveness of the alternative teaching and learning strategies employed in the schools as assessed by teachers, learners and principals.

Given the weighted mean of 2.97 as against the criterion mean of 3.00 in Table 6 , this suggests that the ATLS were not effective. Respondents rated items that indicate high negative influence are: Not being around my classmates during classes affects my learning negatively ( $\bar{x}=4.28$ ), Lack of internet facilities impact negatively on online classes ( $\bar{x}=4.12$ ), Practical-oriented subjects involving experiments become challenging with online teaching $(\bar{x}=4.08)$, Students cannot interact with their teachers and peers ( $\bar{x}=4.06$ ), Remote teaching does not include the children with special needs $(\bar{x}=3.91)$, and I get distracted while learning from home $(\bar{x}=3.75)$.

Table 6: Effectiveness of the Alternative Teaching and Learning Strategies in the Public Secondary Schools

\begin{tabular}{|c|c|c|c|c|c|c|c|c|c|c|c|c|}
\hline \multirow[t]{2}{*}{ Item } & \multicolumn{2}{|c|}{ SD } & \multicolumn{2}{|c|}{ D } & \multicolumn{2}{|c|}{$\mathbf{N}$} & \multicolumn{2}{|c|}{ A } & \multicolumn{2}{|c|}{ SA } & \multirow[t]{2}{*}{ Mean } & \multirow[t]{2}{*}{ SD } \\
\hline & $\mathrm{n}$ & $\%$ & $\mathrm{n}$ & $\%$ & $\mathrm{n}$ & $\%$ & $\mathrm{n}$ & $\%$ & $\mathrm{n}$ & $\%$ & & \\
\hline $\begin{array}{l}\text { The quality of interaction } \\
\text { is as good as face-to-face } \\
\text { interaction. }\end{array}$ & 554 & 60.2 & 97 & 10.5 & 40 & 4.3 & 119 & 12.9 & 110 & 12.0 & 2.06 & 1.50 \\
\hline $\begin{array}{l}\text { I get distracted while } \\
\text { learning from home. }\end{array}$ & 44 & 4.8 & 69 & 7.5 & 55 & 6.0 & 661 & 71.8 & 91 & 9.9 & 3.75 & 0.91 \\
\hline $\begin{array}{l}\text { I learn better not seeing my } \\
\text { teacher during classes. }\end{array}$ & 260 & 28.3 & 408 & 44.3 & 96 & 10.4 & 125 & 13.6 & 31 & 3.4 & 2.19 & 1.09 \\
\hline $\begin{array}{l}\text { My level of concentration } \\
\text { is better with online classes } \\
\text { than in school. }\end{array}$ & 71 & 7.7 & 663 & 72.1 & 84 & 9.1 & 66 & 7.2 & 36 & 3.9 & 2.28 & 0.86 \\
\hline
\end{tabular}




\begin{tabular}{|c|c|c|c|c|c|c|c|c|c|c|c|c|}
\hline \multirow[t]{2}{*}{ Item } & \multicolumn{2}{|c|}{ SD } & \multicolumn{2}{|c|}{ D } & \multicolumn{2}{|c|}{$\mathbf{N}$} & \multicolumn{2}{|c|}{$\mathbf{A}$} & \multicolumn{2}{|c|}{ SA } & \multirow[t]{2}{*}{ Mean } & \multirow[t]{2}{*}{ SD } \\
\hline & $\mathrm{n}$ & $\%$ & $\mathrm{n}$ & $\%$ & $\mathrm{n}$ & $\%$ & $\mathrm{n}$ & $\%$ & $\mathrm{n}$ & $\%$ & & \\
\hline $\begin{array}{l}\text { Not being around my } \\
\text { classmates during classes } \\
\text { affects my learning } \\
\text { negatively. }\end{array}$ & 36 & 3.9 & 71 & 7.7 & 70 & 7.6 & 170 & 18.5 & 573 & 62.3 & 4.28 & 1.13 \\
\hline $\begin{array}{l}\text { Virtual environment is } \\
\text { more conducive than } \\
\text { school. }\end{array}$ & 286 & 31.1 & 405 & 44.0 & 105 & 11.4 & 94 & 10.2 & 30 & 3.3 & 2.11 & 1.06 \\
\hline $\begin{array}{l}\text { Students' participation is } \\
\text { well monitored during } \\
\text { virtual class. }\end{array}$ & 83 & 9.0 & 563 & 61.2 & 112 & 12.2 & 125 & 13.6 & 37 & 4.0 & 2.42 & 0.97 \\
\hline $\begin{array}{l}\text { My parents provide me } \\
\text { with laptop and other } \\
\text { incentives for online } \\
\text { classes. }\end{array}$ & 104 & 11.3 & 601 & 65.3 & 92 & 10.0 & 96 & 10.4 & 27 & 2.9 & 2.28 & 0.90 \\
\hline $\begin{array}{l}\text { I have good mastery of } \\
\text { personal computer } \\
\text { essential for online classes. }\end{array}$ & 53 & 5.8 & 642 & 69.8 & 87 & 9.5 & 116 & 12.6 & 22 & 2.4 & 2.36 & 0.86 \\
\hline $\begin{array}{l}\text { Lack of internet facilities } \\
\text { impact negatively on } \\
\text { online classes. }\end{array}$ & 41 & 4.5 & 51 & 5.5 & 67 & 7.3 & 357 & 38.8 & 404 & 43.9 & 4.12 & 1.06 \\
\hline 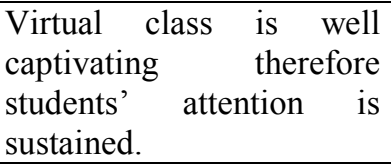 & 29 & 3.2 & 621 & 67.5 & 102 & 11.1 & 123 & 13.4 & 45 & 4.9 & 2.49 & 0.94 \\
\hline $\begin{array}{l}\text { The amount of learning } \\
\text { that has taken place can be } \\
\text { measured. }\end{array}$ & 228 & 24.8 & 460 & 50.0 & 73 & 7.9 & 118 & 12.8 & 41 & 4.5 & 2.22 & 1.09 \\
\hline $\begin{array}{l}\text { Students cannot interact } \\
\text { with their teachers and } \\
\text { peers. }\end{array}$ & 29 & 3.2 & 84 & 9.1 & 56 & 6.1 & 385 & 41.8 & 366 & 39.8 & 4.06 & 1.05 \\
\hline $\begin{array}{l}\text { Practical-oriented subjects } \\
\text { that involve experiments } \\
\text { become challenging with } \\
\text { on-line teaching. }\end{array}$ & 27 & 2.9 & 67 & 7.3 & 80 & 8.7 & 381 & 41.4 & 365 & 39.7 & 4.08 & 1.02 \\
\hline $\begin{array}{l}\text { Remote teaching does not } \\
\text { include the children with } \\
\text { special needs. }\end{array}$ & 33 & 3.6 & 40 & 4.3 & 52 & 5.7 & 647 & 70.3 & 148 & 16.1 & 3.91 & 0.84 \\
\hline
\end{tabular}

The test of hypothesis also showed that though there was no statistically significant difference between students and teachers assessment of the effectiveness of ATLS employed in the schools, significant differences exist between the principal and teachers and also between the principal and students in their assessment of the effectiveness of ATLS employed in the schools.

These findings corroborate that of Abbey and Hoxley (2020) that the interventions adopted were immediate responses to the crisis without prior large-scale implementation. Hence, facilitating practical-oriented subjects that will typically engage students through laboratory experiments was challenging. It is only very few schools that can afford to set up and maintain virtual science laboratories where students and teachers can work together to simulate experiments. Similarly, Lawal (2020) noted that teachers have not been trained to teach at a distance on the use of e-learning devices because teaching online is much more difficult than teaching face-to-face. In addition, the education of children with special needs has also been threatened.

\section{Conclusions}

This paper has provided further insight into the way COVID-19 has impacted the activities of public secondary schools in South-West Nigeria, and the findings could be generalized to a country-wide study. The alternative learning strategies introduced by the government in public secondary schools in the wake of the COVID-19 pandemic in South-West Nigeria were not effective. This is because virtual classes did not take care of all the subjects taught in school, as corroborated by TEP \& NESG (2020). Hence, teaching online became much more 
difficult than teaching face-to-face as a result of the attendant challenges encountered by students, teachers and principals.

\section{Recommendations}

Stakeholders in public secondary schools should embrace COVID-19 and the resulting challenges for education as a transformative occurrence that could lead to innovation and a modern world for educators and students.

Government should take into consideration learners in remote areas while adopting the online teaching and learning platform as an alternative teaching-learning method. This will bridge the gap in accessing online teachinglearning facilities for all.

The online teaching and learning process should be made attractive to both teachers and learners through adequate provisions of palliatives and facilities capable of aiding the process.

Virtual classes should be designed to accommodate all the subjects taught in the schools with particular reference to practical-oriented subjects. This could be achieved through online practical demonstration of these subjects by the facilitators.

Training opportunities aimed at building the capacity of teachers in the use of different online strategies appropriate for learners in different locations should be provided, considering their peculiarities.

\section{References}

Abbey, B. \& Hoxley, D. (2020). Laboratory experiments in the pandemic moved online or mailed home to university students. The Conversation Africa, Inc. http://theconversation.com/labexperiments $=$ in $=$ the $=$ pandemic $=$ moved-online-or-mailed-home-to-uni-students- 138794

Addi, R. A., Benksim, A., Ainine, M. \& Cherkaoul, M. (2020). COVID-19 Outbreak and Perspective in Morocco. European Journal of General Medicine 17(4): 2516-3507.

Amorighoye, T. A. (2020). Covid-19 has exposed the education divide in Nigeria. This is how we can close it. World Economic Forum Covid Action Plan. www.weforum/agenda/2020/06/education-nigeria-covid-19. Accessed 25/9/2021

Bai, Y., Yao. L., Wei, T., Tian, F., Jin, D.Y., Chen, L. \& Wang, M. (2020). Presumed asymptomatic carrier transmission of COVID-19. JAMA. American Medical Association 323(14):j 1406-1407.

Digital 2020 Global Overview Report. https//datareportal.com/report/digital-2020-nigeria.

Fakoya, F. (2020). COVID-19 and young girls: Expect increases in child marriage and teen pregnancy. Ms Magazine. http://msmagazine.com/2020/04/20/covid-19-and-young-girls-expect-increases-in-childmarriage-and-teen-pregnancy/

Henry, G. \& Agbadi, M. (2020). Rethinking Inclusive Education: COVID19 realities, post implications on education (online). Nairametrics.com Available: http;//files.eric.ed.gov. Mastercard Foundation, Data Science Nigeria/Malezilaunch Learn at Home Initiative for disadvantaged school children.

Laccarino, M. (2019). Water, population growth and contagious diseases", Water, 11(2): 386.

Lawal, I. (2020). Why Nigeria must invest in open distance learning by Prof. Jegede. The Guardian. https//guardian.ng/features/why-nigeria-must-invest-in-open-distance-learning-by-prof-jegede

Marbot, O. (2020). Coronavirus Africa Map: which countries are most at risk? https://www.theafricareport.com/23948/coronavirus-africa-which-countries-are-most-at-risk/.

Mezirow, J. (1997). Transformative Learning: Theory to Practice, p. 8. https://cmapsconverted.ihmc.us/rid=1MCY1CBS9-W00F4X-15W8/Transformative-Learning-Mezirow1997.pdf Accessed: 10/9/2021.

NBS (2020). National Bureau of Statistics Poverty and Inequality in Nigeria: Executive Summary (2019). Report Date: May 2020. Data Source: National Bureau of Statistics.

NCDC (2020). Nigeria Centre for Disease Control - Protecting the health of Nigerians. 07 September $2020 \mid$ Abuja. Public Health Advisory on COVID-19. https://ncdc.gov.ng/news/262/07-september-2020-\%7Cabuja-\%E2\%80\%93-public-health-advisory-on-covid-19. Accessed:5/9/2021

NCDC (2021). Nigeria Centre for Disease Control Covid-19 Outbreak in Nigeria Situation Report; Abuja, Nigeria, 2021.

Nlebem, A. (2020). Federal Government orders closure of all schools in Nigeria as coronavirus spreads. Business Day. http://businessday.ng.coronavirus/article/fg-orders-closure-of-all-schools-in-nigeria-as-coronavirusspreads/

Obiakor, T. \& Adeniran, A. (2020). COVID-19: Risk-Control measures threatens to deepen Nigeria's education crisis. Centre for the Study of Economies of Africa (CSEA) http://cseaafrica.org/covid-19-risk-controlmeasures-threatens-to-deepen-nigeria- education-crisis/

Ogunode, N. J. (2020). Effects of COVID19 schools close down on academic programme of senior secondary schools in Abaji area council of Federal Capital Territory Abuja, Nigeria. Electronic Research Journal of Social Sciences and Humanities, 2(11):84-94. 
TEP and NESG (2020). Learning in a Pandemic Nigeria's response to teaching and learning during the COVID19 pandemic. Nigerian Economic Summit Group http://bit.ly/TEP-NESG Report Launch June 9, 2020.

UNESCO (2020). With one in five learners kept out of school, UNESCO mobilizes education ministers to face the covid-19 crisis". Archived from the original on 2020-03-12. Retrieved 2021-07-15.

UNICEF (2020), "Keeping the world's children learning through covid-19". www.unicef.org. Retrieved 2020-0722.

UNICEF (2020). United Nations Children's Education Fund (Nigeria Covid-19 situation report http://reliefweb.int/sites/reliefweb.int/files/resources/UNICEF\%20 nigeria $\% 20$ covid$19 \% 20$ situation $\% 20$ report $\% 20 \mathrm{No}_{0} 208 \% 20915 \% 20 \mathrm{May} \% 202020$.pdf.unicef $\% 20$ nigeria $\% 20$ covid19\%20situation\%20report\%208\%20.\%209-15\%20May\%202020pdf. Accessed 6/5/2021.

Vegas, E. (2020). School closures, government responses, and learning inequality around the world during COVID-19. Retrieved June 01, 2020.

WHO (2020). Coronavirus Disease 2019 (COVID-19) Situation Report-61. Available Online at: https://www.who.int/docs/default-source/coronavirus/situation-reports/20200321-sitrep-61-covid-19. Accessed 20/3/2020.

WHO (2021). Coronavirus disease (COVID - 19) advice for the public. Retrieved May 20, 2021, from https://www.who.int/emergencies/diseases/novel-coronavirus-2021/advice-for-public/ 